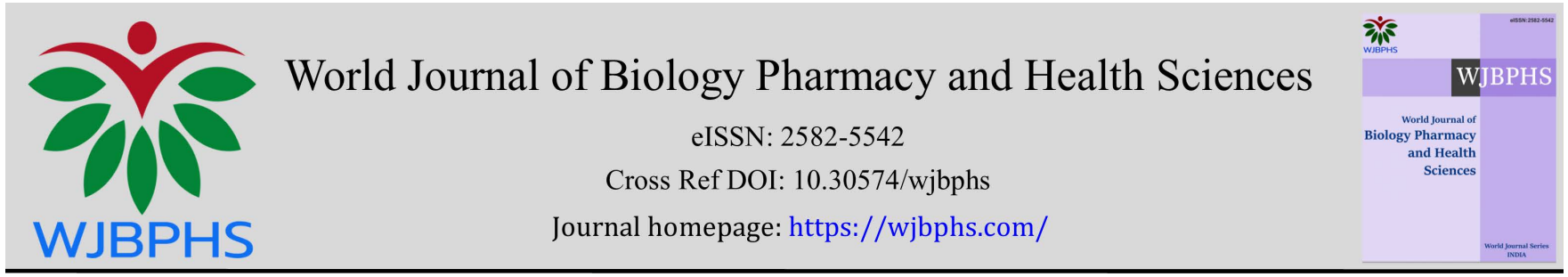

(REVIEW ARTICLE)

\title{
Review on drug delivery system for phytomedicine through mechanism of encapsulation
}

\author{
Pallav Kaushik Deshpande * and Ragini Gothalwal \\ Department of Biotechnology, Barkatullah University, Bhopal (M.P.) 462026. \\ World Journal of Biology Pharmacy and Health Sciences, 2021, 06(01), 010-018 \\ Publication history: Received on 01 March 2021; revised on 04 April 2021; accepted on 06 April 2021
}

Article DOI: https://doi.org/10.30574/wjbphs.2021.6.1.0031

\begin{abstract}
Natural products have limitation in the bioavailability of active components because of numbers of reasons which includes poor solubility of the ingredient, poor stability due to gastric and colonic acidity, poor metabolism by the effect of gut microflora, poor absorption across the intestinal wall, poor active efflux mechanism and first-pass metabolic effects these factors make the failure of clinical trials and efficacy of natural phytochemicals used for human consumption both in cell culture and preclinical animal model systems is distinctly addressed by various researchers. Over the past decades, extraordinary advances have been made successfully on the development of novel drug delivery systems for encapsulation of plant active metabolites including organic, inorganic and hybrid nanoparticles .Various nanosystems and advanced biotechnology systems have been introduced to improve the therapeutic efficacy, safety and market appeal of nutraceuticals and phytochemicals, including liposomes, polymeric micelles, nanoparticles, and phytosomes. The advanced formulas are confirmed to have extraordinary benefits over conventional and previously used systems in the manner of solubility, bioavailability, toxicity, pharmacological activity, stability, distribution, sustained delivery, and both physical and chemical degradation.
\end{abstract}

Keywords: Nano-medicine; Phytomedicine; Biomedical application; Nutraceuticals; Drug delivery system

\section{Introduction}

From the literature it is evident that herbal drugs show their pharmacological action either due to specific constituent or due to combination of constituents.Various ecological factors as well as the time of collection of plant material play crucial role on concentration of phytochemicals, which may varies in batch to batch and directly induce affect on pharmacological response of that particular batch of drug. Best response can be obtained only if phytochemicals are available in concentration ranges with in the therapeutic range of that particular molecule .Any fluctuations above or below the therapeutic concentration lead to either toxic effects or no response. So the titration of dose as well as the determination of dose is necessory. To overcome such cases and to enhance the efficacy of the herbal drug Novel Drug Delivery System (NDDS) play important role, which is a unique blend of various branches of science such as polymer technology, pharmaceutics, immunology, molecular biology, etc. The various novel herbal formulations like polymeric nanoparticles, nanocapsules, liposomes, phytosomes, nanoemulsions, microsphere, transferosomes, and ethosomes has been reported using bioactive phytoconstituents and plant extracts [2]. The novel formulations are reported to have remarkable advantages over conventional formulations of phytochemicals and extracts which include enhancement of solubility, bioavailability, protection from toxicity, enhancement of pharmacological activity, enhancement of stability, improved tissue macrophages distribution, sustained delivery, and also provide protection from physical and chemical degradation of active phytoconstituent [4].

\footnotetext{
* Corresponding author: Pallav Kaushik Deshpande; Email: kaushik.pallav@gmail.com

Department of Biotechnology, Barkatullah University, Bhopal (M.P.) 462026. 
In the past few decades, considerable research has been reported on the development of novel drug delivery system (NDDS) for herbal molecules. The novel carriers should ideally fulfill two prerequisites. Firstly, it should deliver the drug at a rate directed by the needs of the body, over the period of treatment. Secondly, it should target the active molecule to the site of action. Conventional dosage forms including prolonged-release dosage forms fails to meet these characteristics. In phyto-formulation research, developing nanodosage forms (polymeric nanoparticles and nanocapsules, liposomes, solid lipid nanoparticles, phytosomes and nanoemulsion etc.) have a number of advantages for herbal drugs, including enhancement of solubility and bioavailability, protection from toxicity, enhancement of pharmacological activity, enhancement of stability, improving tissue macrophages distribution, sustained delivery, protection from physical and chemical degradation etc. Thus the nano sized novel drug delivery systems of herbal drugs have a potential future for enhancing the activity and overcoming problems associated with plant medicines [6].

\section{Liposome}

Liposomes, which are biodegradable and essentially non-toxic vehicles, can encapsulate both hydrophilic and hydrophobic materials. Liposome based drug delivery systems offer the potential to enhance the therapeutic index of anti-cancer agents, either by increasing the drug concentration in tumor cells and/or by decreasing the exposure in normal tissues exploiting enhanced permeability and retention effect phenomenon and by utilizing targeting strategies. The main advantages of using liposomes include: i) the high biocompatibility, ii) the easiness of preparation, iii) the chemical versatility that allows the loading of hydrophilic, amphiphilic, and lipophilic compounds, and iv) the simple modulation of their pharmacokinetic properties by changing the chemical composition of the bilayer components . Delivery of agents to the reticuloendothelial system (RES) is easily achieved, since most conventional liposomes are trapped by the RES. The application of novel approaches can also improve the efficacy of herbal cosmetic formulations on the human body [17].

The liposomes are spherical particles that encapsulate a fraction of the solvent, in which they freely diffuse (float) into their interior. They can have one, several or multiple concentric membranes. Liposomes are constructed of polar lipids which are characterized by having a lipophilic and hydrophilic group on the same molecules. Upon interaction with water, polar lipids self-assemble and form self-organized colloidal particles. Simple examples are detergents, components form micelles, while polar lipids with bulkier hydrophobic parts cannot associate into micelles with high curvature radii but form bilayers which can self-close into liposomes or lipid vesicles. A cross-section of a liposome depicts the hydrophilic heads of the amphiphile orienting towards the water compartment while the lipophilic tails orient away from the water towards the center of the vesicle, thus forming a bilayer [8]. Consequently, water soluble compounds are entrapped in the water compartment and lipid soluble compounds aggregate in the lipid section. Uniquely, liposomes can encapsulate both hydrophilic and lipophilic materials. Liposomes usually formed from phospholipids, have been used to change the pharmacokinetics profile of, not only drugs, but herbs, vitamins and enzymes. Because of their unique properties liposomes are able to enhance the performance of products by increasing ingredient solubility, improving ingredient bioavailability, enhanced intracellular uptake and altered pharmacokinetics and biodistribution and in vitro and in vivo stability. Liposomes as a drug delivery system can improve the therapeutic activity and safety of drugs, mainly by delivering them to their site of action and by maintaining therapeutic drug levels for prolonged periods of time. Among various advantages associated with liposomes the noteworthy are:

- Solubility enhancement

- Enhancement of bioavailability

- Programmed targeting

- Prolongation of duration of action

- As they are lipoidal in constitution they enhance the tissue macrophagial uptake of the entrapped constituents.

- Stability associated problems can also be solved

- Absorption and disposition of the constituents can also be tailored 
Table 1 Liposomal herbal formulation

\begin{tabular}{|c|c|c|c|c|c|c|}
\hline Formulations & $\begin{array}{l}\text { Active } \\
\text { ingredients }\end{array}$ & $\begin{array}{l}\text { Applications of } \\
\text { liposome } \\
\text { formulations }\end{array}$ & Biological activity & $\begin{array}{l}\text { Method of } \\
\text { preparation }\end{array}$ & $\begin{array}{l}\text { \% } \\
\text { Entrapment } \\
\text { efficiency }\end{array}$ & $\begin{array}{l}\text { Route of } \\
\text { administ } \\
\text { ration }\end{array}$ \\
\hline $\begin{array}{l}\text { Quercetin } \\
\text { liposomes }\end{array}$ & $\begin{array}{l}\text { Quercetin } \\
\text { Reduced } \\
\text { dose }\end{array}$ & $\begin{array}{l}\text { enhance penetration } \\
\text { in blood brain } \\
\text { barrier }\end{array}$ & $\begin{array}{l}\text { Antioxidant } \\
\text { Anticancer }\end{array}$ & $\begin{array}{l}\text { Reverse } \\
\text { evaporation } \\
\text { technique }\end{array}$ & $60 \%$ & $\begin{array}{l}\text { Intranasa } \\
\text { l }\end{array}$ \\
\hline $\begin{array}{l}\text { Liposomes } \\
\text { encapsulated }\end{array}$ & $\begin{array}{l}\text { silymarin } \\
\text { Silymarin }\end{array}$ & $\begin{array}{l}\text { Improve } \\
\text { bioavailability }\end{array}$ & Hepatoprotective & $\begin{array}{l}\text { Reverse } \\
\text { evaporation } \\
\text { technique }\end{array}$ & $69.22 \pm 0.6 \%$ & Buccal \\
\hline $\begin{array}{l}\text { Liposoma } \\
\text { artemisia } \\
\text { arborescens }\end{array}$ & $\begin{array}{l}\text { Artemisia } \\
\text { arborescens } \\
\text { essential oil }\end{array}$ & $\begin{array}{l}\text { Targeting of } \\
\text { essential oils to cells, }\end{array}$ & $\begin{array}{l}\text { enhance } \\
\text { penetration into, } \\
\text { cytoplasmatic } \\
\text { barrier }\end{array}$ & $\begin{array}{l}\text { Antiviral Film } \\
\text { method and } \\
\text { sonication }\end{array}$ & $60-74 \%$ & In vitro \\
\hline $\begin{array}{l}\text { Ampelopsin } \\
\text { liposome }\end{array}$ & Ampelopsin & Increase efficiency & Anticancer Film- & $\begin{array}{l}\text { ultrasound } \\
\text { method }\end{array}$ & $62.30 \%$ & In vitro \\
\hline $\begin{array}{l}\text { Paclitaxel } \\
\text { liposome }\end{array}$ & Paclitaxel & $\begin{array}{l}\text { High entrapment } \\
\text { efficiency and } \mathrm{PH} \\
\text { sensitive }\end{array}$ & Anticancer & $\begin{array}{l}\text { Thin film } \\
\text { hydration } \\
\text { method }\end{array}$ & $94 \%$ & In vitro \\
\hline $\begin{array}{l}\text { Curcumin } \\
\text { liposome }\end{array}$ & Curcumin & $\begin{array}{l}\text { Long circulating } \\
\text { with } \\
\text { entrapment } \\
\text { efficiency }\end{array}$ & Anticancer & $\begin{array}{l}\text { Ethanol } \\
\text { injection } \\
\text { method }\end{array}$ & $88.27 \pm 2.16 \%$ & In vitro \\
\hline $\begin{array}{l}\text { Colchicine } \\
\text { Liposomes }\end{array}$ & Colchicine & $\begin{array}{l}\text { Enhance skin } \\
\text { accumulation, } \\
\text { prolong drug release } \\
\text { and improve site } \\
\text { specificity }\end{array}$ & Antigout Rotary & $\begin{array}{l}\text { evaporation } \\
\text { sonication } \\
\text { method }\end{array}$ & $66.3 \pm 2.2 \%$ & Topical \\
\hline $\begin{array}{l}\text { Catechins } \\
\text { liposomes }\end{array}$ & Catechins & $\begin{array}{l}\text { Increased } \\
\text { permeation through } \\
\text { skin }\end{array}$ & $\begin{array}{l}\text { Antioxidant and } \\
\text { chemopreventive }\end{array}$ & $\begin{array}{l}\text { Rotary } \\
\text { evaporation } \\
\text { sonication } \\
\text { method }\end{array}$ & $93.0 \pm 0.1$ & $\begin{array}{l}\text { Transder } \\
\text { mal }\end{array}$ \\
\hline $\begin{array}{l}\text { Breviscapine } \\
\text { liposomes }\end{array}$ & Breviscapin & $\begin{array}{l}\text { Sustained delivery } \\
\text { of breviscapine }\end{array}$ & $\begin{array}{l}\text { Cardiovascular } \\
\text { diseases }\end{array}$ & $\begin{array}{l}\text { Double } \\
\text { emulsification } \\
\text { process }\end{array}$ & $87.9 \pm 3.1 \%$ & $\begin{array}{l}\text { Intramus } \\
\text { cular }\end{array}$ \\
\hline
\end{tabular}

\section{Nanoparticles}

In recent year, the nanonization of herbal medicines has attracted much attention. Nanoparticles and nanoemulsions are colloidal systems with particles varying in size from $10 \mathrm{~nm}$ to $1000 \mathrm{~nm}$. Nanoparticle systems with mean particle size well above the $100 \mathrm{~nm}$ standard have also been reported in literature, including nanonized curcuminoids , paclitaxel and praziquantel which have a mean particle size of 450,147.7, and even higher than $200 \mathrm{~nm}$, respectively. In addition, nanoparticles could also be defined as being submicronic (b1 lm) colloidal systems. The nanospheres have a matrix type structure in which the active ingredient is dispersed throughout (the particles), whereas the nanocapsules have a polymeric membrane and an active ingredient core. Nanonization possesses many advantages, such as increasing compound solubility, reducing medicinal doses, and improving the absorbency of herbal medicines compared with the respective crude drugs preparations. Various advantages of nanoparticles include:

- Enhanced shelf life of product

- Possibility of tailoring surface characteristics

- Enhancement of solubility

- Minimization of adverse reaction associated with dose

- Targeting to specific locus in the body

- Hydrophilic as well as lipophilic both type of drugs can be incorporated. 
Table 2 Nanoparticle formulations

\begin{tabular}{|c|c|c|c|c|c|c|}
\hline Formulations & $\begin{array}{l}\text { Active } \\
\text { ingredients }\end{array}$ & $\begin{array}{l}\text { Applications of } \\
\text { liposome } \\
\text { formulations }\end{array}$ & $\begin{array}{l}\text { Biological } \\
\text { activity }\end{array}$ & $\begin{array}{l}\text { Method of } \\
\text { preparation }\end{array}$ & $\begin{array}{l}\% \text { Entrapment } \\
\text { efficiency }\end{array}$ & $\begin{array}{l}\text { Route of } \\
\text { administration }\end{array}$ \\
\hline $\begin{array}{l}\text { Triptolide } \\
\text { nanoparticle }\end{array}$ & Triptolide & $\begin{array}{l}\text { Enhance the } \\
\text { penetration of drugs } \\
\text { through the stratum } \\
\text { corneum by } \\
\text { increased hydration }\end{array}$ & $\begin{array}{l}\text { Anti } \\
\text { inflammato } \\
\text { ry }\end{array}$ & $\begin{array}{l}\text { Emulsification } \\
\text { ultrasound }\end{array}$ & Not reported & Topical (skin) \\
\hline $\begin{array}{l}\text { Nanoparticles } \\
\text { of Cuscuta } \\
\text { chinensis, }\end{array}$ & $\begin{array}{l}\text { Flavonoids and } \\
\text { lignans }\end{array}$ & $\begin{array}{l}\text { Improve } \quad \text { water } \\
\text { solubility }\end{array}$ & $\begin{array}{l}\text { Hepatoprot } \\
\text { ective and } \\
\text { antioxidant } \\
\text { effects }\end{array}$ & $\begin{array}{l}\text { Nanosuspensio } \\
\mathrm{n} \text { method }\end{array}$ & $90 \%$ & Oral \\
\hline $\begin{array}{l}\text { Triptolide- } \\
\text { loaded solid } \\
\text { lipid } \\
\text { nanoparticle }\end{array}$ & Triptolide & $\begin{array}{l}\text { Decreasing the } \\
\text { toxicity }\end{array}$ & $\begin{array}{l}\text { Anti- } \\
\text { inflammato } \\
\text { ry }\end{array}$ & $\begin{array}{l}\text { Emulsification- } \\
\text { ultrasound }\end{array}$ & Not reported & Oral \\
\hline $\begin{array}{l}\text { Artemisinin } \\
\text { nanocapsules }\end{array}$ & Artemisinin & $\begin{array}{l}\text { Sustained drug } \\
\text { release }\end{array}$ & Anticancer & $\begin{array}{l}\text { Self-assembly } \\
\text { procedure }\end{array}$ & $90-93 \%$ & In vitro \\
\hline $\begin{array}{l}\text { Radix salvia } \\
\text { miltiorrhiza } \\
\text { nanoparticles } \\
\text { Upto }\end{array}$ & $\begin{array}{l}\text { R. Salvia } \\
\text { miltiorrhiza }\end{array}$ & $\begin{array}{l}\text { Improve the } \\
\text { bioavailability }\end{array}$ & $\begin{array}{l}\text { Coronary } \\
\text { heart } \\
\text { diseases, } \\
\text { angina } \\
\text { pectoris and } \\
\text { myocardial } \\
\text { infarction }\end{array}$ & $\begin{array}{l}\text { Spray-drying } \\
\text { technique }\end{array}$ & $96.68 \%$ & In vitro \\
\hline $\begin{array}{l}\text { Quercetin- } \\
\text { loaded } \\
\text { nanoparticles }\end{array}$ & Quercetin & $\begin{array}{l}\text { Increase antioxidant } \\
\text { activity and release } \\
\text { of the drug } 74 \text { times } \\
\text { higher }\end{array}$ & Antioxidant & $\begin{array}{l}\text { Nanoprecipitati } \\
\text { on technique }\end{array}$ & over $99 \%$ & In vitro \\
\hline $\begin{array}{l}\text { Breviscapine- } \\
\text { loaded } \\
\text { nanoparticles }\end{array}$ & Breviscapine & $\begin{array}{l}\text { Prolong the half-life } \\
\text { and decrease RES } \\
\text { uptake }\end{array}$ & $\begin{array}{l}\text { Cardiovascu } \\
\text { lar and } \\
\text { cerebrovasc } \\
\text { ular }\end{array}$ & $\begin{array}{l}\text { Spontaneous } \\
\text { emulsification } \\
\text { solvent } \\
\text { diffusion } \\
\text { technique }\end{array}$ & $93.1 \%$ & Intra Venous \\
\hline $\begin{array}{l}\text { Curcuminoids } \\
\text { solid lipid } \\
\text { nanoparticles }\end{array}$ & Curcuminoids & $\begin{array}{l}\text { Prolonged-release of } \\
\text { the curcuminoids }\end{array}$ & $\begin{array}{l}\text { Anticancer } \\
\text { and } \\
\text { antioxidant }\end{array}$ & $\begin{array}{l}\text { Micro-emulsion } \\
\text { technique }\end{array}$ & $70 \%$ & In vitro \\
\hline $\begin{array}{l}\text { CPT- } \\
\text { encapsulated } \\
\text { nanoparticles }\end{array}$ & Camptothecin & $\begin{array}{l}\text { Prolonged blood } \\
\text { circulation and high } \\
\text { accumulation in } \\
\text { tumors }\end{array}$ & Anticancer & $\begin{array}{l}\text { Dialysis } \\
\text { method }\end{array}$ & $80 \%$ & In vitro \\
\hline
\end{tabular}

\section{Phytosome}

Over the past century, phytochemical and phytopharmacological sciences established the compositions, biological activities and health promoting benefits of numerous plant products. Most of the biologically active constituents of plants are polar or water soluble molecules. However, water soluble phytoconstituents (like flavonoids, tannins, terpenoids, etc.) are poorly absorbed either due to their large molecular size which cannot absorb by passive diffusion, or due to their poor lipid solubility; severely limiting their ability to pass across the lipid-rich biological membranes, resulting poor bioavailability [14]. It has often been observed that the isolation and purification of the constituents of an extract may lead to a partial or total loss of specific bio-activity for the purified constituent — the natural constituent synergy becomes lost. Very often the chemical complexity of the crude or partially purified extract seems to be essential for the bioavailability of the active constituents. Extracts when taken orally some constituents may be destroyed in the gastric environment. As standardized extracts are established, poor bioavailability often limits their clinical utility due 
to above said reasons. It has been observed that complexation with certain other clinically useful nutrients substantially improves the bioavailability of such extracts and their individual constituents. The nutrients so helpful for enhancing the absorption are the phospholipids [3].

Phytosome is a patented technology developed by a leading manufacturer of drugs and nutraceuticals, to incorporate standardized plant extracts or water soluble phytoconstituents into phospholipids to produce lipid compatible molecular complexes, called as phytosomes and so vastly improve their absorption and bioavailability table 3 has a list of few formulations. In liposomes no chemical bond is formed; the phosphatidylcholine molecules surround the water soluble substance. There may be hundreds or even thousands of phosphatidylcholine molecules surrounding the water soluble compound. In contrast, with the phytosome process the phosphatidylcholine and the plant components actually form a 1:1 or a 2:1 molecular complex depending on the substance (s) complexed, involving chemical bonds. Phospholipids are complex molecules that are used in all known life forms to make cell membranes. In humans and other higher animals the phospholipids are also employed as natural digestive aids and as carriers for both fat-miscible and water miscible nutrients [16]. They are miscible both in water and in lipid environments, and are well absorbed orally. Phytosomes are more bioavailable as compared to conventional herbal extracts owing to their enhanced capacity to cross the lipoidal biomembrane and finally reaching the systemic circulation. Phytosome has been an emerging trend in delivery of herbal drugs and nutraceuticals.

Advantages of Phytosome include:

- High lipophilicity

- Enhanced bioavailability

- High stability

Table 3 Phytosomal herbal formulations

\begin{tabular}{|c|c|c|c|c|c|c|}
\hline Formulations & $\begin{array}{l}\text { Active } \\
\text { ingredients }\end{array}$ & $\begin{array}{l}\text { Applications of } \\
\text { liposome } \\
\text { formulations }\end{array}$ & $\begin{array}{l}\text { Biological } \\
\text { activity }\end{array}$ & $\begin{array}{l}\text { Method of } \\
\text { preparation }\end{array}$ & $\begin{array}{l}\text { \% Entrapment } \\
\text { efficiency }\end{array}$ & $\begin{array}{l}\text { Route of } \\
\text { administratio } \\
n\end{array}$ \\
\hline $\begin{array}{l}\text { Ginkgo biloba } \\
\text { phytosomes }\end{array}$ & Flavonoids & $\begin{array}{l}\text { Flavonoids of GBP } \\
\text { stabilize the ROS } \\
\text { Cardio-protective }\end{array}$ & $\begin{array}{l}\text { antioxidant } \\
\text { activity }\end{array}$ & $\begin{array}{l}\text { Phospholipids } \\
\text { complexation }\end{array}$ & $\begin{array}{l}100 \mathrm{mg} \text { and } 200 \\
\mathrm{mg} / \mathrm{kg}\end{array}$ & Subcutaneous \\
\hline $\begin{array}{l}\text { Ginkgoselect } \\
\text { phytosome }\end{array}$ & Flavonoids & $\begin{array}{l}\text { Inhibits lipid } \\
\text { peroxidation } \\
\text { (LPO), stabilize } \\
\text { the ROS }\end{array}$ & $\begin{array}{l}\text { Hepatoprotect } \\
\text { ive, } \\
\text { antioxidant }\end{array}$ & $\begin{array}{l}\text { Phospholipids } \\
\text { complexation }\end{array}$ & 25 and $50 \mathrm{mg} / \mathrm{kg}$ & Oral \\
\hline $\begin{array}{l}\text { Naringenin } \\
\text { phytosomes }\end{array}$ & Naringenin & $\begin{array}{l}\text { Prolonged } \\
\text { duration of action }\end{array}$ & $\begin{array}{l}\text { Antioxidant } \\
\text { activity }\end{array}$ & $\begin{array}{l}\text { Naringenin- } \\
\text { phospholipid } \\
\text { complex }\end{array}$ & $100 \mathrm{mg} / \mathrm{kg}$ & Oral \\
\hline $\begin{array}{l}\text { Curcumin } \\
\text { phytosomes }\end{array}$ & Curcumin & $\begin{array}{l}\text { Increase } \\
\text { antioxidant } \\
\text { activity and } \\
\text { Increase } \\
\text { bioavailability }\end{array}$ & $\begin{array}{l}\text { Antioxidant, } \\
\text { anticancer }\end{array}$ & $\begin{array}{l}\text { Curcumin- } \\
\text { phospholipid } \\
\text { complexation }\end{array}$ & $360 \mathrm{mg} / \mathrm{kg}$ & Oral \\
\hline $\begin{array}{l}\text { Hawthorn } \\
\text { Phytosome }\end{array}$ & Flavonoids & $\begin{array}{l}\text { Increase } \\
\text { therapeutic } \\
\text { efficacy and } \\
\text { absorption }\end{array}$ & $\begin{array}{l}\text { Cardio- } \\
\text { protective and } \\
\text { antihypertensi } \\
\text { ve }\end{array}$ & $\begin{array}{l}\text { Phospholipids } \\
\text { Complexation }\end{array}$ & $100 \mathrm{mg}$ & Oral \\
\hline $\begin{array}{l}\text { Quercetin } \\
\text { phytosome }\end{array}$ & Quercetin & $\begin{array}{l}\text { Exerted better } \\
\text { therapeutic } \\
\text { efficacy }\end{array}$ & $\begin{array}{l}\text { Antioxidant, } \\
\text { anticancer }\end{array}$ & $\begin{array}{l}\text { Quercetin- } \\
\text { phospholipid } \\
\text { complexation }\end{array}$ & & Oral \\
\hline $\begin{array}{l}\text { Grape seed } \\
\text { phytosome }\end{array}$ & Procyanidins & $\begin{array}{l}\text { The blood TRAP } \\
\text { nTotal Radical- } \\
\text { trapping } \\
\text { Antioxidant } \\
\text { Parameter) were } \\
\text { significantly }\end{array}$ & $\begin{array}{l}\text { antioxidant, } \\
\text { cardio- } \\
\text { protective }\end{array}$ & $\begin{array}{l}\text { Phospholipids } \\
\text { complexation }\end{array}$ & $50-100 \mathrm{mg}$ & Oral \\
\hline
\end{tabular}




\begin{tabular}{|l|l|l|l|l|l|l|}
\hline & & $\begin{array}{l}\text { elevated over the } \\
\text { control Systemic }\end{array}$ & & \\
\hline $\begin{array}{l}\text { Silybin } \\
\text { phytosome }\end{array}$ & Flavonoids & $\begin{array}{l}\text { Absorption of } \\
\text { silybin phytosome } \\
\text { from silybin is } \\
\text { approximately } \\
\text { seven times } \\
\text { greater }\end{array}$ & $\begin{array}{l}\text { Hepatoprotect } \\
\text { ive, } \\
\text { antioxidant } \\
\text { for liver and } \\
\text { skin }\end{array}$ & $\begin{array}{l}\text { Silybinphospho } \\
\text { lipid } \\
\text { complexation }\end{array}$ & $120 \mathrm{mg}$ & Oral \\
\hline $\begin{array}{l}\text { Ginseng } \\
\text { phytosome, }\end{array}$ & Ginsenoside & $\begin{array}{l}\text { Increase } \\
\text { absorption } \\
\text { Nutraceutical }\end{array}$ & $\begin{array}{l}\text { Immunomodu } \\
\text { lators }\end{array}$ & $\begin{array}{l}\text { Phospholipids } \\
\text { complexation }\end{array}$ & $150 \mathrm{mg}$ & Oral \\
\hline $\begin{array}{l}\text { Green tea } \\
\text { phytosome, }\end{array}$ & $\begin{array}{l}\text { Epigallocatechi } \\
\mathrm{n}\end{array}$ & $\begin{array}{l}\text { Increase } \\
\text { absorption } \\
\text { Nutraceutical }\end{array}$ & $\begin{array}{l}\text { systemic } \\
\text { antioxidant, } \\
\text { anticancer }\end{array}$ & $\begin{array}{l}\text { Phospholipids } \\
\text { complexation }\end{array}$ & $50-100 \mathrm{mg}$ & Oral \\
\hline
\end{tabular}

\section{Microsphere}

They are spherical matrix based systems varying $1 \mu$ - $300 \mu$ in size, in which drug is uniformly dispersed in polymeric matrix. Various techniques that can be adopted in the synthesis of microspheres are single emulsion technique, double emulsion technique, Polymerization techniques (normal as well as interfacial), and spray drying and spray congealing, phase separation coacervation method and solvent extraction technique. First ordered release kinetics is generally followed in such systems where the release rate limiting steps are diffusion and dissolution. Firstly the outer dissolution media will diffuse the matrix make the entrapped drug to solublise in it and then the drug is released from the system this is one type of mechanism in other type the system constituting polymer show surface erosion behavior where the surface erode layer by layer and the release of drug occurs. There main factors are there which influence the released amount as well as its rate. They are:

- Size- Smaller the size more will be the surface area, lesser will be the path length to diffuse or lesser layers required to erode for drug release

- Type of matrix - It depends on way in which matrix show its release

- Polymer concentration- It is inversely proportional to the amount of drug released.

Microspheres have various advantages which make them a suitable carrier for drug delivery. Noteworthy among them are:

- Their ingestability and injectability

- Ability to give sustain release profile

- Specificity towards a particular locus with in the body (immuno microspheres)

\section{Emulsions}

Emulsion refers to a non-homogeneous dispersion system that is composed of two kinds of liquids unable to dissolve each other, and one of which disperse in the other one in a form of droplets. Generally, emulsion is composed of oil phase, water phase, surfactant and sub-surfactant. Its appearance is translucent to transparent liquid. Emulsion can be classified into ordinary emulsion (0.1-100 $\mu \mathrm{m})$, micro-emulsion $(10-100 \mathrm{~nm})$, sub-micro-emulsion (100-600 nm), etc. Among them, the micro-emulsion is also called nanoemulsions, and the sub-micro-emulsion is also called lipid emulsion. As a drug delivery system, emulsion distributes in vivo in the targeted manner due to its affinity to the lymph. In addition, the drug can be sustained release in a long time because the drug is packaged in the inner phase and kept off direct touch with the body and tissue fluid. After the oily drugs or lipophilic drugs being made into $0 / \mathrm{W}$ or $0 / \mathrm{W} / 0$ emulsion, the oil droplets are phagocytosised by the macrophage and get a high concentration in the liver, spleen, and kidney in which the amount of the dissolved drug is very large. While water soluble drug is produced into $\mathrm{W} / \mathrm{O}$ or $\mathrm{W} / \mathrm{O} / \mathrm{W}$ emulsion, it can be easily concentrated in the lymphatic system by intramuscular or subcutaneous injection. The size of the emulsion particle has an impact on its target distribution.

Apart from its targeted sustained release, producing the herbal drug into emulsion will also strengthen the stability of the hydrolyzed materials, improve the penetrability of drugs to the skin and mucous, and reduce the drugs' stimulus to tissues. So far, some kinds of herbal drugs, such as camptothecin, Brucea javanica oil, coixenolide oil and zedoary oil 
have been made into emulsion. Elemenum emulsion is a type of new anti-cancer drug with great application prospects [1]. Furthermore, it has no marrow inhibition and no harm to the heart and liver.

Advantages of micro-emulsion:

- Solubilisation capacity

- $\quad$ Sustained release of drugs

- High stability

- Simplicity of manufacture

- Bioavailability improvement

\section{Other novel vesicular herbal formulations}

Transferosomes are applied in a non-occluded method to the skin, which permeate through the stratum corneum lipid lamellar regions as a result of the hydration or osmotic force in the skin. It can be applicable as drug carriers for a range of small molecules, peptides, proteins and herbal ingredients. Transferosomes can penetrate stratum corneum and supply the nutrients locally to maintain its functions resulting maintenance of skin in this connection the transferosomes of Capsaicin has been prepared by Xiao et al. [18] which shows the better topical absorption in comparison to pure capsaicin. Ethosome, as a novel liposome, is especially suitable as a topical or transdermal administration carrier. Ethosome has a high deformability and entrapment efficiency and can penetrate through the skin completely and improve drug delivery through the skin. Compared to other liposomes, the physical and chemical properties of ethosomes make the delivery of the drug through the stratum corneum into a deeper skin layer efficiently or even into the blood circulation. This property is very important as the topical drug carrier and transdermal delivery system. Moreover, the ethosomes carrier also can provide an efficient intracellular delivery for both hydrophilic and lipophilic drugs, percutaneous absorption of matrine an anti-inflammatory herbal drug is increased; it also permits the antibacterial peptide to penetrate into the fibrocyte easily. The roles of these types of novel vasicular system over herbal drug delivery are summarized in.

\section{Microspheres}

Administration of medication via micro particulate systems is advantageous because microspheres can be ingested or injected and; they can be tailored for desired release profiles and used site-specific delivery of drugs and in some cases can even provide organ-targeted release [7] So far, a series of plant active ingredients, such as rutin, camptothecin, zedoary oil, tetrandrine, quercetine and Cynara scolymus extract has been made into microspheres. In addition, reports on immune microsphere and magnetic microsphere are also common in recent years [12]. Immune microsphere possesses the immune competence as a result of the antibody and antigen was coated or adsorbed on the polymer microspheres.

Advantages of microspheres:

- Facilitate accurate delivery of small amount of potential drug

- Controlled release of drug

- Protect unstable drug

- Enhanced bioavailability

\section{Proprietary novel drug delivery system}

Proprietary novel drug delivery system of plant actives and extracts Cosmetochem International AG is a Swiss-based company, specialized in the production of high quality, customized botanical extracts and actives, launch botanical, standardized, liposomal powders named Liposome Herbasec $₫$ a novel range of standardized botanical extracts in a liposomal-based powder form. As the liposome carriers are very effective penetration enhancers which serve as carriers to the skin, increasing the bioavailability of the plant extracts. In present formulation the freeze-dried dispersion of Liposome Herbasec $®$ is reformed when dispersed in water, re-encapsulatingthe concentrated plant extract. Phospholipids used for the preparation of formulation are the safest, mildest substances which allow the penetration of the plant actives into the deeper layers of the epidermis and avoid the use of solvents. There are five extracts in the current Liposome Herbasec $®$ range which are standardized for specific phytochemicals. 
Similarly the other vesicular systems like nanoemulsion, ethosomes and transferosomes are highly useful assemblies and find various advantages in the delivery of herbal medicines [15]. The phytosome process has also been applied to many popular herbal extracts including Ginkgo biloba, grape seed, hawthorn, milk thistle, green tea, and ginseng. The flavonoid and terpenoid components of these herbal extracts lend themselves quite well for the direct binding to phosphatidylcholine. Phytosome is produced by binding individual components of herbal extracts to phosphatidyl choline, resulting in a dosage form that is better absorbed and thus, produces better results than the conventional herbal extracts. The results indicate that the absorption of silybin from silybin phytosome is approximately seven times greater compared to the absorption of silybin from regular milk thistle extract. Drugs can be embedded or dissolved in nanoparticles and can also be adsorbed or coupled on the surface. Encapsulating drugs within NPs can improve the solubility and pharmacokinetics of drugs, and, in some cases, enable further clinical development of new chemical entities that have stalled because of poor pharmacokinetic properties [13]. The major carrier materials of nanoparticles are synthetic biodegradable high molecular polymer and natural polymer. The former usually includes poly- $\alpha$ cyanoacrylate alkyl esters, polyvinyl alcohol, polylactic acid, and polylacticcoglycolic acid, etc. The latter is usually divided into two classes: proteins (albumin, gelatin and vegetable protein) and polysaccharides (cellulose, starch and its derivatives, alginate, chitin and chitosan, etc.).

\section{Conclusion}

An extensive research is going on in the area of novel drug delivery and targeting for plant actives and extracts. However, research in this area is still at the exploratory stage. Many problems in the research, production and application need to be solved. In addition, more attention should be paid to the research on the carrier materials in order to develop more suitable carriers which can reduce the toxicity of drugs, enhance their activity and improve the overall quality of the agents. Herbal drugs have enormous therapeutic potential which should be explored through some value added drug delivery systems. Lipid solubility and molecular size are the major limiting factors for drug molecules to pass the biological membrane to be absorbed systematically following oral or topical administration. Several plant extracts and phytomolecules, despite having excellent bio-activity in vitro demonstrate less or no in vivo actions due to their poor lipid solubility or improper molecular size or both, resulting poor absorption and poor bioavailability. Standardized plant extracts or mainly polar phytoconstituents like flavonoids, terpenoids, tannins, xanthones when administered through novel drug delivery system show much better absorption profile which enables them to cross the biological membrane, resulting enhanced bioavailability. Hence more amount of active constituent becomes present at the site of action (liver, brain, heart, kidney, etc.) at similar or less dose as compared to the conventional plant extract or phytomolecule. Hence, the therapeutic action becomes enhanced, more detectable and prolonged. Several excellent phytoconstituents have been successfully delivered using NDDS. Hence there is a great potential in the development of novel drug delivery systems for the plant actives and extracts.

\section{Compliance with ethical standards}

\section{Acknowledgments}

UGC for the financial assistance for study, under the scheme of Post-doctoral fellowship for women (PDFWM).

\section{Disclosure of conflict of interest}

All authors declare that there is no conflict of interest.

\section{References}

[1] Alexis F, Basto P, Levy NE, Radovic MAF, Zhang LF, Pridgen E. HER-2-Targeted Nanoparticle Antiibody Bioconjugates for Cancer Therapy. Chem Med Chem. 2008; 3: 1839-43.

[2] Atmakuri LR, Dathi S. Current trends in herbal medicines. Journal of Pharm Res. 2010; 3: 109-113.

[3] Bhattacharya S. Phytosomes: Emerging strategy in delivery of herbal drugs and nutraceuticals. Pharm Times. 2009; 41: 9-12.

[4] Chan ES, Yim ZH, Phan SH, Mansa RF, Ravindra P. Encapsulation of herbal aqueous extract through absorption with calcium alginate hydrogel beads. Food and Bioproducts Processing. 2010; 88: 195-201.

[5] Chanchal D, Swarnlata S. Novel approaches in herbal cosmetics. Journal of Cosmet Dermatol. 2008; 7: 89-95. 
[6] Chauhan NS, Rajan G, Gopalakrishna B. Phytosomes: A potential phyto phospholipid carriers for herbal drug delivery. J Pharm Res. 2009; 2: 12677.

[7] Garg R, Gupta GD. Gastro retentive floating microspheres of Silymarin: Preparation and in vitro evaluation. Tropical Journal of Pharm Res. 2010; 9: 59-66.

[8] Gortzi 0, Lalas S, Chinou L. Re evaluation of bioactivity and antioxidant activity of myrtus communis extract before and after encapsulation in liposome. Eur Food Res Technol. 2008; 226: 583-90.

[9] He ZF, Liu DY, Zeng S, Ye JT. Study on preparation of ampelopsin liposomes. Journal of Chine Mat Med. 2008; 33 : 27-30.

[10] Hitesh Verma, Shyam Baboo Prasad, Yashwant, Harmanpreet Singh. Herbal Drug Delivery System: A Modern Era Prospective International Journal of Current Pharmaceutical Review and Research. 2013; 4(3): 88-101.

[11] Hong W, Chen DW, Zhao XL, Qiao MX, Hu HY. Preparation and study in vitro of long-circulating nanoliposomes of curcumin. Zhongguo Zhong Yao Za Zhi. 2008; 33: 889-92.

[12] Mei Z, Chen H, Weng T, Yang Y, Yang X. Solid lipid nanoparticle and microemulsion for topical delivery of triptolide. Eur J Pharm Biopharm. 2003; 56: 189-96.

[13] Natrajan V, Madhan B, Sehgal P. Formulation and evaluation of qucertin polycaprolactone microsphere for the treatment of Rheumatoid arthritis. Journal of Pharma Sophora alopecuroides sci. 2010; 100: 195-205.

[14] Rane S, Prabhakar B. Formulation and Evaluation of pH-Sensitive, Long circulating Liposomes for Paclitaxel Delivery. International Journal of Pharm Technol Res. 2009; 1: 914-17.

[15] Saraf AS. Applications of novel drug delivery system for herbal formulations. Fitoterapia. 2010; 81: 680-89.

[16] Semalty A, Semalty M, Rawat MS. The phyto phospholipid complexes phytosomes: A potential therapeutic approach for herbal hepatoprotective drug delivery. Pcog Rev. 2007; 1: 36974.

[17] Sharma G, Anabousi S, Ehrhardt C, Ravi Kumar MN. Liposomes as targeted drug delivery systems in the treatment of breast cancer. Journal of Drug Target. 2006; 14: 30110.

[18] Xiao L, Zhang YH, Xu JC, Jin XH. Preparation of floating rutin-alginate-chitosan microcapsule. Chin Trad Herb Drugs. 2008; 2: 209-12. 